\title{
Induction of spermatogenesis after stem cell therapy of azoospermic guinea pigs
}

\author{
Mehrdokht Hajihoseini ${ }^{1,2}$, Akbar Vahdati ${ }^{1,2}$, Seyed Ebrahim Hosseini ${ }^{1,2}$, \\ Davood Mehrabani ${ }^{3 *}$, and Amin Tamadon ${ }^{3 *}$
}

\author{
${ }^{1}$ Department of Biology, Fars Science and Research Branch, Islamic Azad University, Fars, Iran \\ ${ }^{2}$ Department of Biology, Shiraz Branch, Islamic Azad University, Shiraz, Iran \\ ${ }^{3}$ Stem Cell Technology Research Center, Shiraz University of Medical Sciences, Shiraz, Iran
}

HAJIHOSEINI, M., A. VAHDATI, S. E. HOSSEINI, D. MEHRABANI, A. TAMADON: Induction of spermatogenesis after stem cell therapy of azoospermic guinea pigs. Vet. arhiv 87, 333-350, 2017.

\section{ABSTRACT}

Bone marrow-derived mesenchymal stem cells (BM-MSCs) provide a large quantitative alternative source for regenerative medicine. This study was undertaken to determine the effect of BM-MSCs in the treatment of busulfan-induced azoospermia in guinea pigs. BM-MSCs were isolated from the femur bones of 6 adult guinea pigs as the donor group, and characterized by morphology, MSC markers and osteogenic and adipogenic differentiation. A dose of $40 \mathrm{mg} / \mathrm{kg}$ of busulfan was administered at a 21 day interval to induce azoospermia in 6 guinea pigs. Thirty-five days after the second injection of busulfan, transplantation of $1 \times 10^{6} \mathrm{BM}-\mathrm{MSCs}$ was performed into the seminiferous tubules of the left testes. The right testis was considered as the positive busulfan treated control. The testes of the donor group were applied as an intact normal control. Then, 60 days after cell therapy, histopathological and histomorphometric evaluations of the testes were performed. The seminiferous tubules treated with BM-MSCs, similar to the intact group, showed a normal appearance of spermatogenesis in comparison to the busulfan-induced azoospermic testes. In conclusion, BM-MSCs were effective in the treatment of azoospermia in a guinea pig model where they restore the fertility of busulfaninduced azoospermic animals after transplantation of BM-MSCs. Therefore, this report could open a window in future to the possibility of BM-MSCs transplantation in the treatment of azoospermia in humans, but more studies should be undertaken for further verification.

Key words: bone marrow, mesenchymal stem cell, busulfan, azoospermia, guinea pig

\footnotetext{
*Corresponding author:

Davood Mehrabani, DVM, PhD and Amin Tamadon, DVM, PhD; Stem Cell Technology Research Center, Shiraz University of Medical Sciences, Shiraz, Iran, Phone/Fax:+98 713612 2240-2; E-mail: mehrabad@sums.ac.ir; amintamaddon@yahoo.com
} 


\section{Introduction}

Azoospermia is a health issue among about $1 \%$ of men, occurring in obstructive or non-obstructive forms and is found in $10-15 \%$ of all infertile men (GUDELOGLU and PAREKATTIL, 2013). Non-obstructive azoospermia has been shown to occur as a result of congenital or genetic abnormalities, exposure to gonadotoxins, infectious agents, varicocele, traumas, medications such as chemotherapy drugs, endocrine disorders, and idiopathic causes (BEROOKHIM and SCHLEGEL, 2014). In spite of hormonal or surgical treatments, the outcome of azoospermia treatment is usually unsatisfactory (BEROOKHIM and SCHLEGEL, 2014). Nowadays, cell transplantation has been introduced for treatment of male infertility resulting from the failure of germ cells to proliferate and differentiate, especially for treatment of sperm deformity and azoospermia (O'BRIEN et al., 2010).

This approach to treatment of azoospermia by cell therapy began to be investigated more intensively after successful spermatogonia transplantation in different species (GOOSSENS et al., 2013). Then, the development of in vitro methods of germ cell production, using various sources of stem cells, showed that embryonic stem cells (BUCAY et al., 2009) induced pluripotent stem cells (YANG et al., 2012), and mesenchymal stem cells (NAYERNIA et al., 2006) can be differentiated into male germ cells. On the other hand, mesenchymal stem cells have been isolated from various tissues, including bone marrow (ASADI-YOUSEFABAD et al., 2015), adipose tissue (SHATERZADEH-YAZDI et al., 2015), endometrium (MEHRABANI et al., 2014), dental pulp (MAHDIYAR et al., 2014), and menstrual blood (MEHRABANI et al., 2015a), which all have the potential of being a selected source for mesenchymal stem cell therapy of azoospermia. All these together open up a new way for investigation of transplantation of mesenchymal stem cells as a therapeutic method for azoospermia.

The accumulated evidence suggests that bone marrow harbors mesenchymal stem cells (BM-MSCs), hematopoietic stem cells, endothelial stem cells, and multipotential adult progenitor cells (EHNINGER and TRUMPP, 2011; MORRISON and SCADDEN, 2014). The capability of differentiation of adult BM-MSCs into several non-reproductive tissue cells has been confirmed (JIANG et al., 2002). Regarding male fertility, adult BM-MSCs from mice and humans, grown in vitro in the presence of retinoic acid, were found to express germ cell markers and could differentiate into germ cells (NAYERNIA et al., 2006). Therefore, injection of BM-MSCs into the seminiferous or testicular tissue of different animal species, as models of azoospermia, has been performed. Transplantation of BMMSCs into the seminiferous tubule of a busulfan-treated, infertile mouse model (LUE et al., 2007) and into the testicular tissue of rat model (MONSEFI et al., 2013) could induce spermatogenesis. In guinea pigs (Cavia porcellus), in comparison with other rodents such as mice and rats regarding spermatogenesis, differences were found in relation to the extent of meiotic divisions and the higher number of cells entering meiosis during the first 
wave in guinea pigs (RODRÍGUEZ-CASURIAGA et al., 2011). Although the seminiferous tubules of guinea pigs are highly enriched in meiotic cells as compared with mice and rats, there has been no study to evaluate the effects of stem cell therapy on the model of guinea pig azoospermia. Therefore, this study was performed to use busulfan for induction of azoospermia and BM-MSCs for cell therapy in this model.

\section{Materials and methods}

Animals. Twelve male outbred Dunkin-Hartley guinea pigs (black and brown coat color), weighing 500-550 g, were purchased and kept in polypropylene cages in the Laboratory Animal Center, Shiraz University of Medical Sciences. They were maintained at a controlled temperature $\left(20-22^{\circ} \mathrm{C}\right)$ and a period of $12 \mathrm{~h}$ lightness/darkness (7.00-19.00 lightning) with free access to food and water. All animal procedures were approved by the Ethical Committee of Shiraz University of Medical Sciences. The guinea pigs were divided into two groups: azoospermic-induced and control $(\mathrm{n}=6)$. The control group was used as cell donors and also their left testis was used as a negative control. In the azoospermic group, the left testis of the azoospermia-induced guinea pigs were treated with BM-MSC and their right testis served as a positive control.

Isolation of BM-MSCs. BM-MSCs were isolated from the femurs of euthanized guinea pigs. Both ends of the bone were cut and the BM was flushed out using a $10 \mathrm{~mL}$ syringe filled with Dulbecco's modified eagle medium (DMEM; Biovet, Bulgaria) and $1 \%$ penicillin streptomycin (Sigma, USA). After extraction, bone marrow was transferred on ice to the laboratory, under sterile conditions, and BM-MSCs culture and isolation were performed according to the method of ASADI-YOUSEFABAD et al. (2015). Briefly, bone marrow was diluted with an equal volume of DMEM and centrifuged at $1200 \mathrm{rpm}$ for $7 \mathrm{~min}$. The precipitate was plated in $75 \mathrm{~cm}^{2}$ flasks containing DMEM, supplemented with $10 \%$ fetal bovine serum (FBS; Biovet, Bulgaria), 1\% penicillin and streptomycin and $1 \%$ l-glutamine (Sigma, USA), and transferred into a $\mathrm{CO}_{2}$ incubator at $37{ }^{\circ} \mathrm{C}$ with $5 \% \mathrm{CO}_{2}$ and saturated humidity. The medium was changed after $24 \mathrm{~h}$ and then every $72 \mathrm{~h}$, to remove the non-adherent cells. Adherent cells were subcultured when they were $80 \%$ confluent by washing twice with phosphate buffer saline (PBS, Gibco, USA) and using $0.25 \%$ trypsin (Gibco, USA) for 3-4 min. To inactivate enzyme activity, the same volume of supplemented DMEM media was added. Cell passage continued until passage 3.

Freezing and thawing of BM-MSCs. To coordinate between azoospermia model preparation and cell isolation and characterization, it was necessary to cryopreserve the isolated cells for further steps of the research. For this purpose, in passage 3 the confluent flasks of BM-MSCs were treated with 0.25\% trypsin (Gibco, USA) for 3-4 min and then the enzyme was inactivated by equal amounts of supplemented DMEM media. The cell suspension was centrifuged at $1500 \mathrm{rpm}$ for $5 \mathrm{~min}$, the supernatant removed 
and the precipitate was suspended in a mixture of 50\% DMEM media, $40 \% \mathrm{FBS}$, and $10 \%$ dimethyl sulfoxide (DMSO; MP Bio), at a density of $2 \times 10^{6}$ viable cells $/ \mathrm{ml}$, and was aliquoted into sterile plastic labeled cryovials. They were frozen at $-20{ }^{\circ} \mathrm{C}$ for one hour and then at $-70^{\circ} \mathrm{C}$ for $24 \mathrm{~h}$, and finally transferred to liquid nitrogen for long-term storage. Whenever BM-MSCs were needed, they were taken out for thawing and culturing. To thaw the cells, the cryovials were removed from the liquid nitrogen and placed in a $37{ }^{\circ} \mathrm{C}$ water bath. Then, cell culture DMEM medium was added and the mixture was centrifuged at $1500 \mathrm{rpm}$ for $5 \mathrm{~min}$. The precipitated cells were plated into a culture flask and transferred into an incubator with $5 \% \mathrm{CO}_{2}$ and saturated humidity at $37^{\circ} \mathrm{C}$. The cells were subcultured once after thawing.

BM-MSCs characterization. For confirmation of the mesenchymal characters of MSCs, the isolated and subcultured cells were evaluated for morphology, cell surface markers and potential of differentiation into osteoblast and chondrocyte cell lines, according to ALIBORZI et al. (2016). Using an inverted microscope (Olympus, USA), the morphology of the BM-MSCs cells in different passages was determined.

Expressions of markers for MSCs by reverse transcriptase polymerase chain reaction (RT-PCR) were performed. Briefly, BM-MSCs of passage 3 were used to collect total RNA by a column RNA isolation kit (Denazist-Asia, Iran), according to the manufacturer's protocol. Spectrophotometry was undertaken to assess the concentration of the total RNA. AccuPower ${ }^{\circledR}$ CycleScript RT PreMix (Bioneer, Korea) was used to synthesize the complementary DNAs (cDNAs) according to RNA strains as a template and the kit's instructions. For each reaction, $15 \mu \mathrm{L}$ of total RNA was used to reach a volume up to 20 $\mu \mathrm{L}$ with the diethylpyrocarbonate-treated water (DEPC-water). Twelve thermal cycles were conducted as follows: $30 \mathrm{sec}$ at $20{ }^{\circ} \mathrm{C}$ for primer annealing, $4 \mathrm{~min}$ at $42{ }^{\circ} \mathrm{C}$ for cDNA synthesis, $30 \mathrm{sec}$ at $55^{\circ} \mathrm{C}$ for melting secondary structure and cDNA synthesis, and 5 min at $95^{\circ} \mathrm{C}$ for inactivation. Then, $1 \mu \mathrm{L}$ of template (cDNA) was mixed with other reagents including PCR buffer, taq DNA polymerase, $\mathrm{H}_{2} \mathrm{O}, \mathrm{MgCl}_{2}$, dNTPs, and forward and reverse primers of CD34, CD44 and CD90 (Table 1). Microtubes with $20 \mu \mathrm{L}$ of the mixture were placed in the Thermocycler (Eppendorf, Germany). Thirty amplification cycles were undertaken as follows: initial denaturation at $95^{\circ} \mathrm{C}$ for $5 \mathrm{~min}$ followed by 30 cycles of denaturation at $95{ }^{\circ} \mathrm{C}$ for $30 \mathrm{sec}$; annealing at $64{ }^{\circ} \mathrm{C}, 62{ }^{\circ} \mathrm{C}$, and $61{ }^{\circ} \mathrm{C}$ for 30 $\mathrm{sec}$, respectively and extension at $72{ }^{\circ} \mathrm{C}$ for $30 \mathrm{sec}$; and a final polymerization at $72{ }^{\circ} \mathrm{C}$ for 5 min. PCR products were subsequently assessed using $1.5 \%$ agarose gel electrophoresis next to an appropriate DNA size marker, then stained by power load, visualized under UV light and photographed. 
Table 1. Sequences of reverse transcriptase polymerase chain reaction (RT-PCR) primers used to quantify the expression of bone marrow-derived mesenchymal stem cells specific markers (CD44 and CD90) and hematopoietic stem cells specific markers (CD34) in guinea pig

\begin{tabular}{|l|l|l|}
\hline $\begin{array}{l}\text { Amplicon } \\
\text { length (bp) }\end{array}$ & Primer sequence & Primer \\
\hline 484 & $\begin{array}{l}\text { CAC CAC GGT ATT CAC CAC CA GTG } \\
\text { GAT CCC CAG CTT TTC CA }\end{array}$ & $\begin{array}{l}\text { CD34-F } \\
\text { CD34-R }\end{array}$ \\
\hline 328 & $\begin{array}{l}\text { ACC TGC AGT TTG CAT TGC TG } \\
\text { ACG TGG AAC ACA CCT GCA TA }\end{array}$ & $\begin{array}{l}\text { CD44-F } \\
\text { CD44-R }\end{array}$ \\
\hline 281 & $\begin{array}{l}\text { TGC TGG CAG TCT TAC AGG T } \\
\text { TGT GTA GGT CCC TTC GTC CT }\end{array}$ & $\begin{array}{l}\text { CD90-F } \\
\text { CD90-R }\end{array}$ \\
\hline
\end{tabular}

In order to compare the differentiation potential of BM-MSCs, cells of passage 3 were used, and osteogenic and adipogenic differentiation induced. For osteogenic and adipogenic differentiation, BM-MSCs were seeded in 6-well plates. After the cells reached $70 \%$ confluency, they were cultured for 3 weeks in osteogenic or adipogenic medium. The osteogenic medium contained low glucose DMEM supplement with 100 nM dexamethasone (Sigma-Aldrich), $0.05 \mathrm{mM}$ ascorbate-2-phosphate (Wako Chemicals, Richmond, VA, USA), $10 \mathrm{mM}$ b-glycerophosphate (Sigma-Aldrich), 1\% antibiotic/ antimycotic and 10\% FBS. Adipogenic medium contained DMEM low glucose, 10\% FBS, $0.5 \mathrm{mM}$ isobutyl-methylxanthine (Sigma-Aldrich), 10\% FBS, $1 \mu \mathrm{M}$ dexamethasone, $10 \mu \mathrm{M}$ insulin, $200 \mu \mathrm{M}$ indomethacin (Sigma-Aldrich). The medium was replaced every 3 days. On day 21, the cells were fixed by $10 \%$ formalin solution (Sigma-Aldrich) for 10 minutes. To detect calcified extracellular matrix and osteogenic differentiation, the cells were stained using Alizarin Red (Sigma-Aldrich) and subsequently washed twice with distilled water. Adipogenic differentiation was detected by Oil Red O (Sigma-Aldrich), which specifically stains lipid droplets.

Induction of azoospermia. Busulfan is a chemotherapeutic drug mostly used in cancer patients (BARTELINK et al., 2014) that has been shown to be responsible for impairment of spermatogenesis (PANAHI et al., 2014). This study used busulfan for induction of azoospermia. Guinea pigs were intraperitoneally injected with $40 \mathrm{mg} / \mathrm{kg}$ of busulfan (Busilvex $^{\circledR}$, Pierre Fabre Medicament, Boulogne, France) in 2 doses with a 21 day interval to disrupt spermatogenesis.

Transplantation of BM-MSCs. Thirty-five days after the second busulfan injection, the animals were anesthetized using ketamine $(40 \mathrm{mg} / \mathrm{kg}$, Woerden, Netherlands $)$ and xylazine $\left(0.5 \mathrm{mg} / \mathrm{kg}\right.$ Alfazyne ${ }^{\circledR}, 2 \%$, Woerden, Netherlands). They were placed in dorsal recumbency, and the abdominal area was prepared for further surgery. One cm incision was performed at the abdominal midline to reach the peritoneal cavity. Under a Zeiss OPMI operating microscope (Carl Zeiss Meditec, Jena, Germany), the fat pad attached 
to the left seminiferous and testis was pulled gently by an iris forceps until the testis was taken out and clearly visible. A pulled glass pipette was connected to the tube. For injection of BM-MSCs into testis, it was marked by addition of sterile trypan blue $(1: 1, \mathrm{v} / \mathrm{v})$, which served to monitor the success of the injection, loaded into polyethylene tubing attached to a $1 \mathrm{~mL}$ syringe. The cell suspension was gently pushed into the pipette by pressing the syringe. The seminiferous tubules were identified using a stereomicroscope, while 100 $\mu \mathrm{L}$ of BM-MSCs' mixture ( $10^{6}$ cells) was injected into the lumen of the seminiferous tubules of the busulfan-treated testis (Figs. 1C and 1D). The testis was returned to the abdominal cavity, and the abdominal wall and skin were sutured. The right testis was considered as the control.

Histopathologic and histomorphometric assessment. The duration of spermatogenesis in guinea pigs is approximately 34 days, with four cycles of 8.5 days (NOLLER et al., 1977). It has also been shown that the first spermatogenic wave lasts between 40 and 45 days in guinea pigs (RODRÍGUEZ-CASURIAGA et al., 2011). Therefore, 60 days (approximately 7 expected cycles) after cell transplantation, the animals were euthanized, and both testes were removed and transferred into $10 \%$ formalin buffer solution. After fixation, they were embedded in paraffin, and histopathologic sections were made from each block. Five vertical sections from the polar and the equatorial regions of $5 \mu \mathrm{m}$ thickness were hematoxylin-eosin stained and examined under a light microscope for any spermatogenic activity.

All tubules were evaluated for the presence of any spermatogonia, spermatocytes, and spermatids. Ten identical circular transverse sections were performed in the tubules, each in a different area of the testis, using a systematic random protocol, to assess the stereological indices (PANAHI et al. 2014). The mean seminiferous tubule diameter (d) was determined by taking the average of two diameters, $\mathrm{D}_{1}$ and $\mathrm{D}_{2}$, at right angles. The crosssectional area $\left(A_{c}\right)$ of the seminiferous tubules was determined using the equation: $A_{c}=$ $\pi \mathrm{D}^{2} / 4$, where $\pi$ is equal to 3.142 and $\mathrm{D}$ is the mean diameter of the seminiferous tubules (PANAHI et al., 2014).

A testis was rated for its spermatogenic potential by a modified spermatogenic index on a scale of 0 to 6 (PANAHI et al., 2014). The index was based on the appearance of the spermatogenic cells throughout the testis, and included the number of cell layers, types of cells, and the presence of late spermatids in the seminiferous tubules (PANAHI et al., 2014). The index and criteria were as follows: 0 , no spermatogenic cells; 1 , only spermatogonia present; 2, spermatogonia and spermatocytes present; 3, spermatogonia, spermatocytes and round (early) spermatids present with $<50$ late spermatids per tubule; 4, spermatogonia, spermatocytes, and round spermatids present, and up to 50-100 late spermatids per tubule; 5, spermatogonia, spermatocytes, and round spermatids present, 
and up to 100-150 late spermatids per tubule; and 6, all cell types present and >150 late spermatids per tubule.

Statistical analysis. The data were analyzed using SPSS software (version 18, Chicago, IL, USA). One way ANOVA, followed by LSD post-hoc tests were used for statistical analyses. The spermatogenesis index of seminiferous tubules was compared using the Mann-Whitney U test. $\mathrm{P}<0.05$ was considered significant.

\section{Results}

BM-MSCs characterization. BM-MSCs were adhered to plastic culture flasks and exhibited spindle-shaped morphology. They did not change through all passages (Fig. 1). The isolated BM-MSCs expressed CD44 and CD90 for MSC markers, but not CD34 for hematopoietic cell markers (Fig. 2). After 21 days, BM-MSCs in osteogenic and adipogenic induction media differentiated into osteoblasts and adipocytes, respectively. They revealed calcium deposits by Alizarin Red staining, or cytoplasmic lipid droplets with Oil Red O staining (Fig. 3).

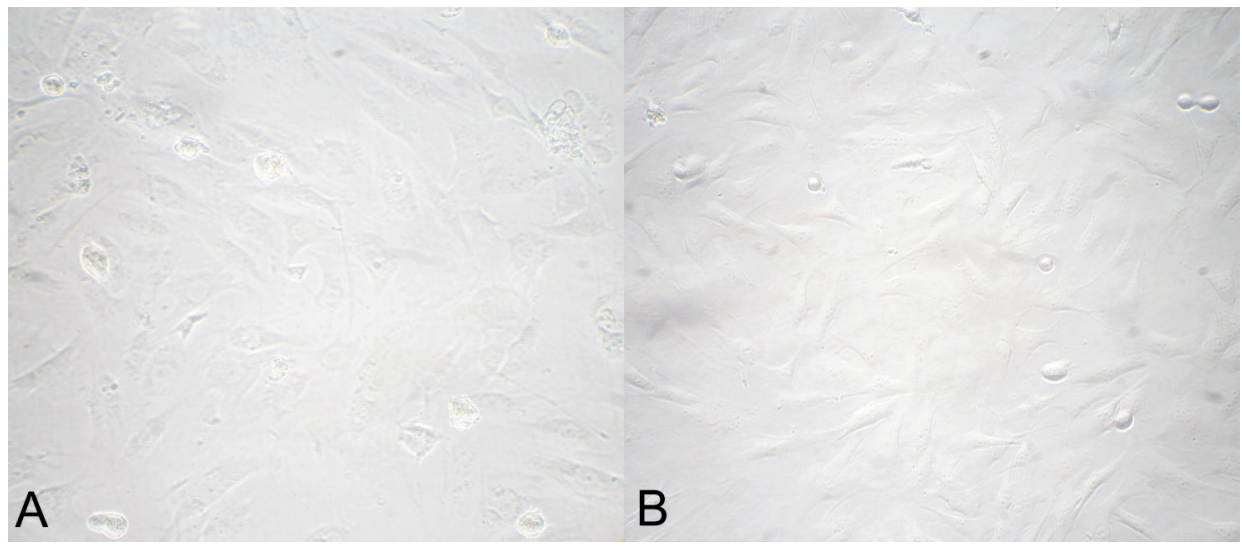

Fig. 1. Spindle shape morphology of guinea pig bone marrow-derived mesenchymal stem cells in passages $1(\mathrm{~A}, \times 200)$ and $3(\mathrm{~B}, \times 100)$

Histopathologic findings. After induction of azoospermia in the guinea pigs with a double injection of $10 \mathrm{mg} / \mathrm{kg}$ of busulfan, the testes of the positive control guinea pigs were microscopically examined for any spontaneous spermatogenesis recovery, and no sign was observed. After the treatment with busulfan, the seminiferous tubules of the testes not treated with BM-MSCs were empty and their spermatogenesis process was disrupted (Fig. 4A). The examination of sections showed only Sertoli cell appearance in the samples without BM-MSCs therapy. Histopathological examination of testes in the busulfan treatment group after 60 days revealed some degenerative changes such 
as seminiferous tubular atrophy and germinal epithelium degeneration in most of the tubules. A large vacuolated lumen occupied the seminiferous tubules and atrophic germinal epithelium covered the peripheral zone of the seminiferous tubules as a thin band (Fig. 4B). Moreover, there were no spermatozoa in the epididymis of the busulfan treated, azoospermic group.

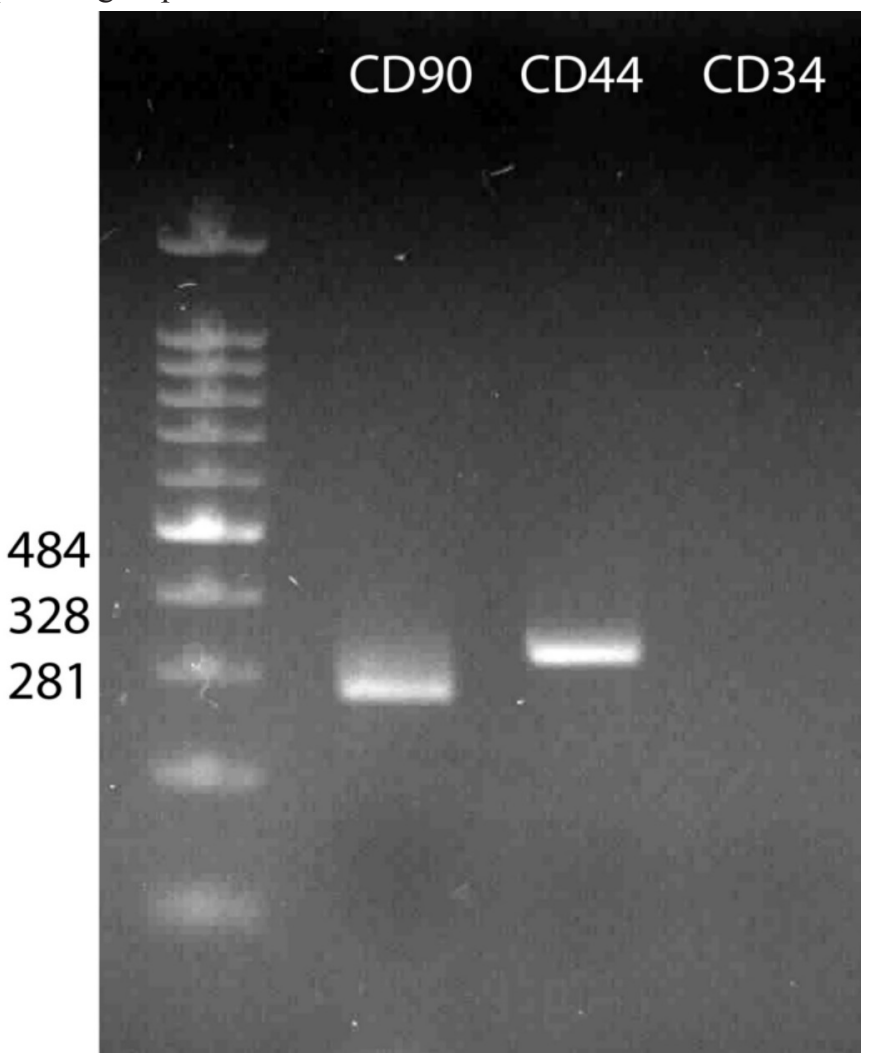

Fig. 2. Agarose gel electrophoresis of products of reverse transcriptase polymerase chain reaction (RT-PCR) revealed to be positive for CD44 and CD90 and absence negative for CD34

However, the presence was observed of spermatogonia in the seminiferous tubules with BM-MSCs transplantation (Fig. 4C). Moreover, the tubules appeared to be filled up with germinal cells (spermatogonia, primary spermatocytes, spermatids and sperms) in the sections of the BM-MSCs-treated testes (Fig. 4D). Most of the epididymis tubes of the cell treated groups had spermatozoa, but some tubes were empty (Fig. 4C). Moreover, 
spermatozoa appeared in the epididymis of the BM-MSCs treated group (Figs. 5E and $5 \mathrm{~F}$ ). In comparison with the treated group, normal intact guinea pigs had more condensed germinal epithelium and all the epididymis tubes were filled with spermatozoa.

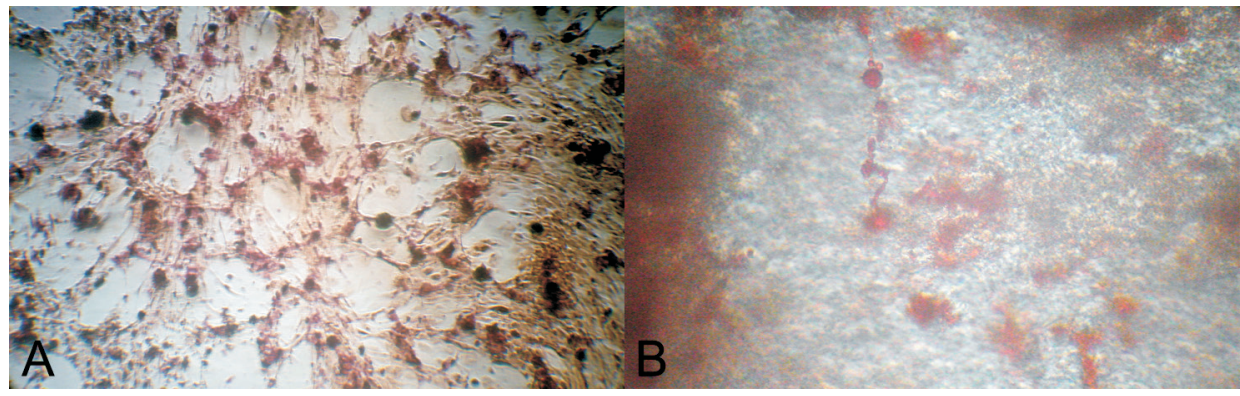

Fig. 3. Osteogenic (A) and adipogenic (B) differentiations of bone marrow-derived mesenchymal stem cells from passage 3 of subcultures by Alizarin Red staining and Oil Red staining, respectively

Histomorphometric findings. Fig. 5 shows the stereological indices of the seminiferous tubules in busulfan-induced azoospermic testis treated with BM-MSCs, in comparison with busulfan-treated testes (positive control) and intact normal testis (negative control) in guinea pigs. There were no significant statistical differences in the luminal diameter and luminal area of the seminiferous tubules of the testes between the busulfan and the BM-MSCs-treated groups $(\mathrm{P}>0.05)$, but both groups had larger luminal diameters and areas of seminiferous tubules than the negative control group $(\mathrm{P}<0.05$, Figs. 6A and $6 \mathrm{~B})$. Furthermore, the cellular diameter and area, total diameter and cross-sectional area of seminiferous tubules of the cell treated and negative control groups were larger than in the busulfan azoospermic testes $(\mathrm{P}<0.05$, Figs. $6 \mathrm{C}, 6 \mathrm{D}, 6 \mathrm{E}$ and $6 \mathrm{~F})$. Interestingly, the cellular diameter and area, total diameter and cross-sectional area of seminiferous tubules cell of the treated groups were larger than in the intact testis of the negative control group $(\mathrm{P}<0.05)$. On the other hand, the spermatogenesis index of the seminiferous tubules in the negative control and the cell therapy testes was significantly higher than in the busulfantreated control testes $(\mathrm{P}<0.05$, Fig. 6). 


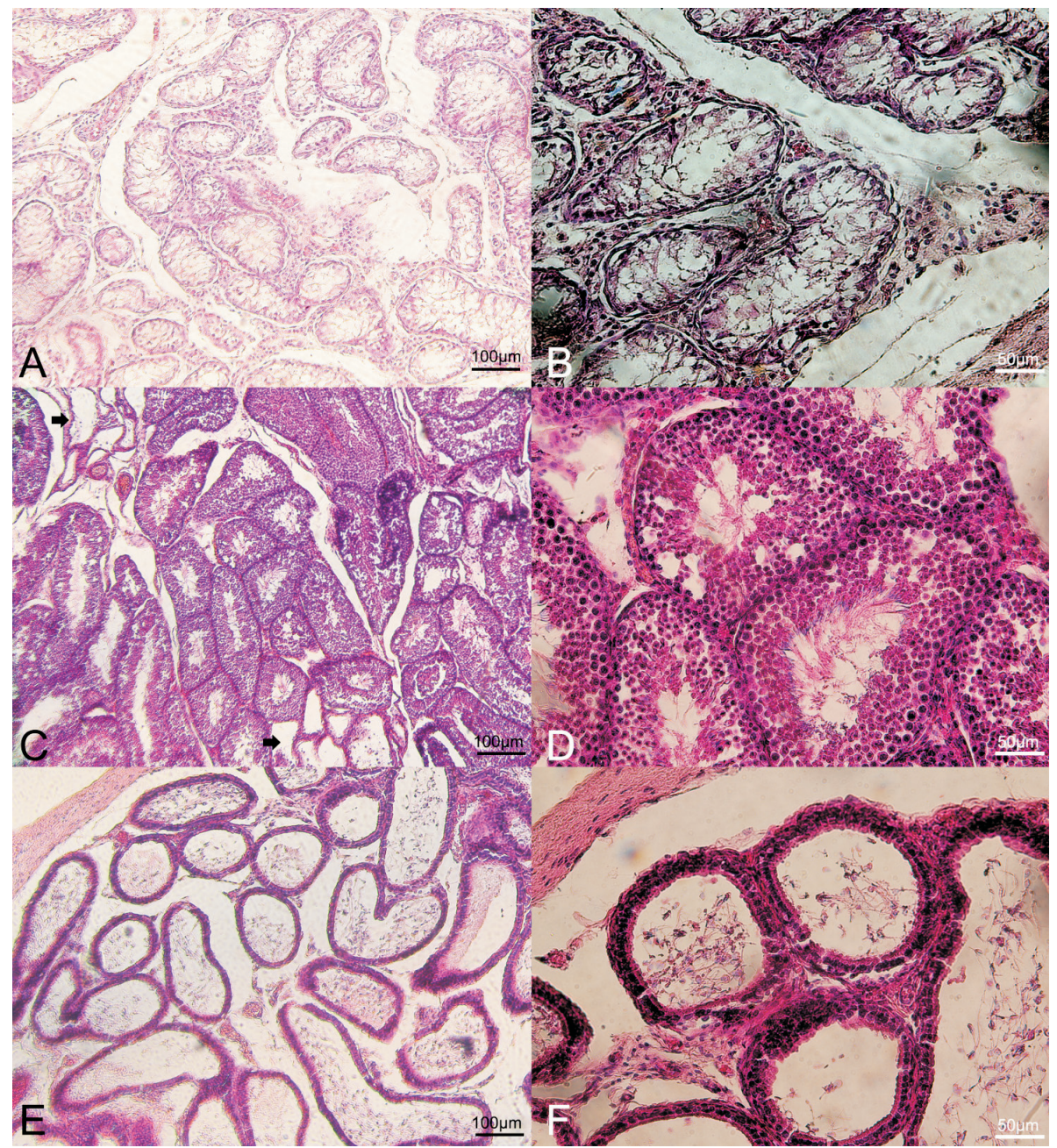

Fig. 4. Histopathologic evaluation of busulfan treated guinea pigs before and after treatment with bone marrow-derived mesenchymal stem cells (BM-MSCs). The seminiferous tubules of busulfan treated testes lack any germinal layer cells, indicating the absence of spermatogenesis (A and B). After transplantation of BM-MSCs into the seminiferous tubules, most tubules appeared to have spermatogenic cells (C and D). Arrows show the untreated seminiferous tubes. Epididymis of the testis treated with BM-MSCs shows the appearance of spermatozoa after cell therapy (E and F). The findings show the positive effect of cell transplantation to reach spermatogenic cells in seminiferous tubules (hematoxylin and eosin staining). 

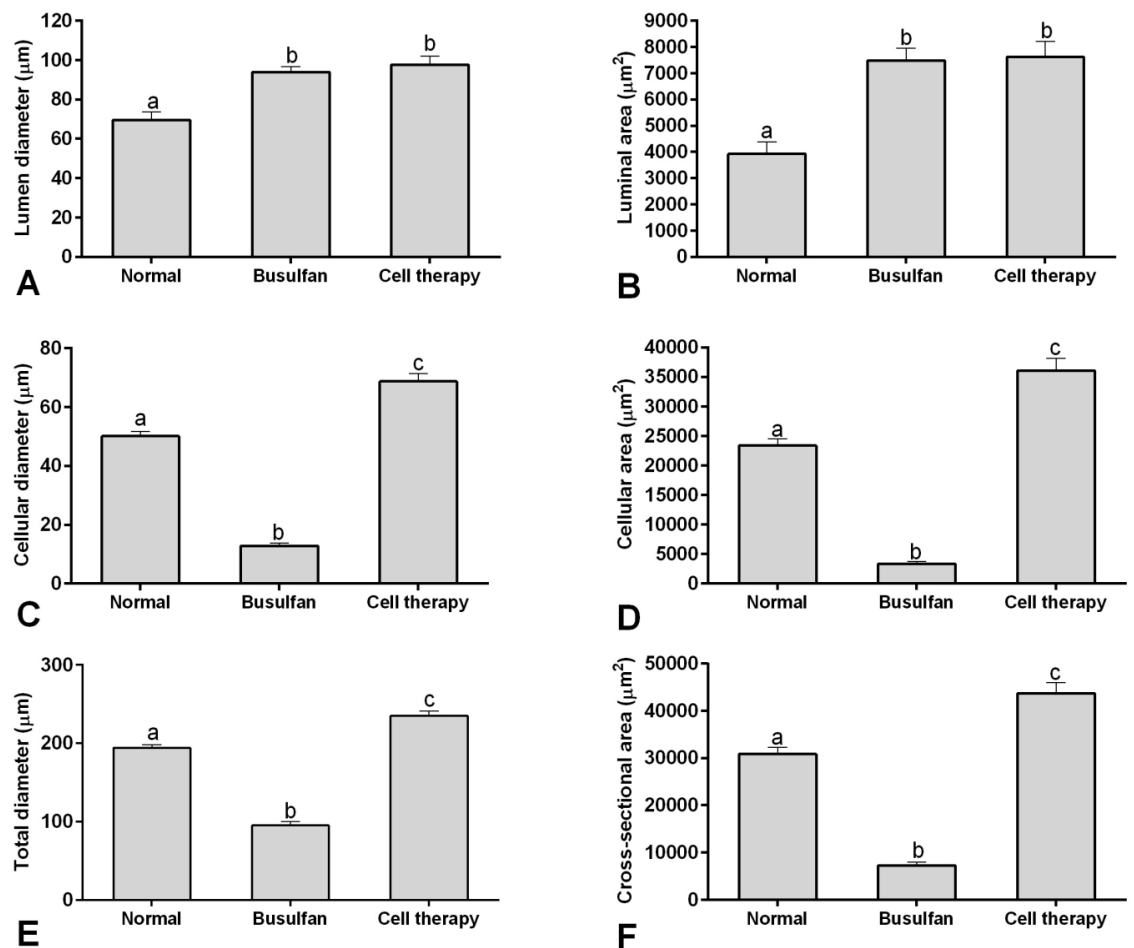

Fig. 5. The mean and standard error of the stereological indices of seminiferous tubules in busulfan-induced azoospermic testis treated with bone marrow-derived mesenchymal stem cells (cell therapy) in comparison with busulfan treated testes (positive control) and intact normal testis (negative control) in guinea pigs. A) lumen diameter $(\mu \mathrm{m}), \mathrm{B})$ luminal area $\left.\left(\mu \mathrm{m}^{2}\right), \mathrm{C}\right)$ cellular diameter $(\mu \mathrm{m}), \mathrm{D})$ cellular area $\left.\left(\mu \mathrm{m}^{2}\right), \mathrm{E}\right)$ total diameters $(\mu \mathrm{m})$, and F) cross sectional area of the tubule $\left(\mu \mathrm{m}^{2}\right)$. ${ }^{\mathrm{a}, \mathrm{b}, \mathrm{c}}$ superscript letters show the statistically significant differences between groups $(\mathrm{P}<0.05)$. 


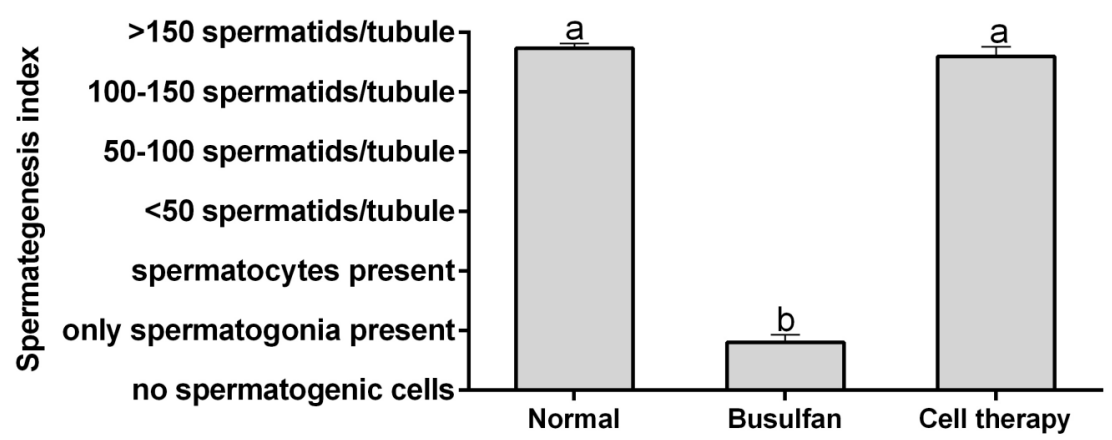

Fig. 6. Mean and standard error of spermatogenesis index of seminiferous tubules in busulfaninduced azoospermic testis treated with bone marrow-derived mesenchymal stem cells (cell therapy) in comparison with busulfan treated testes (positive control) and intact normal testis (negative control) in guinea pigs. ${ }^{\mathrm{a}, \mathrm{b}}$ superscript letters denote a significant difference between groups $(\mathrm{P}<0.05)$.

\section{Discussion}

Our findings showed that BM-MSCs injected into busulfan-induced azoospermia in guinea pigs could induce spermatogenesis. Consistent with our findings, in mice, transplantation of BM-MSCs into the testis of a busulfan-induced infertile mouse model could induce differentiation of these cells into germ, Sertoli and Leydig cells (LUE et al., 2007). However, in contrast to our findings, it was shown that injection of BM-MSCs into the testis of mice could not induce differentiation into germ cells (LASSALLE et al., 2008). In another rodent species, hamsters, intra-seminiferous tubule injection of BM-MSCs activated spermatogenesis in a busulfan-induced azoospermic model (TAMADON et al., 2015). Furthermore, intra-seminiferous tubule injection (ZAHKOOK et al., 2014; ZHANG et al., 2014) and intra-testicular injection of BM-MSCs (MONSEFI et al., 2013) were also found to induce spermatogenesis in the seminiferous tubules of busulfan-induced azoospermic rats. Furthermore, the same results with BM-MSCs therapy were found in a testicular torsion model of azoospermia in rats (SABBAGHI et al., 2012). On the other hand, in rats, treatment of busulfan-induced infertile rats with adipose tissue derived MSCs was also demonstrated to lead to morphologically normal spermatogenesis (CAKICI et al., 2013; MEHRABANI et al., 2015b). Also, transplantation of human umbilical cord MSCs into seminiferous tubules of immunodeficient mice led to the sperm differentiation of those cells (CHEN et al., 2015). Our findings, and consideration of other study results, may explain the recovery mechanisms of spermatogenesis after transplantation of MSCs. The first hypothesis is the differentiation of MSCs into the target cells through proper induction 
conditions (GNECCHI and MELO, 2009). The success of in vitro differentiation of BMMSCs into germ cells and spermatozoa was previously reported (DRUSENHEIMER et al., 2007). The second hypothesis is the secretion of growth factors by MSCs that stimulate the resident spermatogonia to restore the function of the host cells (LEATHERMAN, 2013). This hypothesis may be supported by consideration of the method of azoospermia induction in the present study, when busulfan had no effects on DNA synthesis, however, when busulfan intoxicated the cells in the G1 phase, it could inhibit the next mitosis stage (DE ROOIJ and VERGOUWEN, 1990). The last mechanism is the merging of MSCs with endogenous seminiferous tubule cells to recover the injured tissue function (MANSOUR et al., 2012). Incidentally, without paying attention to the mechanism and MSCs source, all these animal models showed that MSCs therapy can be beneficial to reduce the side effects of chemotherapy on spermatogenesis.

Furthermore, although donor and recipient animals were not syngeneic, and despite the immune-competitive character of the donor guinea pigs, allotransplantation of BMMSCs into the seminiferous tubules of busulfan-induced azoospermic guinea pigs had therapeutic effects. Commenting on this topic, three points may be noticed. The first is the immune privilege character of seminiferous tubules. Certain sites of some tissues in immunocompetent wild type mammalians are immune privileged, including the eye, the brain, the pregnant uterus (NIEDERKORN, 2006) and the testicles (MEINHARDT and HEDGER, 2011). Sertoli cells were shown to be immune tolerant cells that can facilitate the survival and protection of allogenic transplanted BM-MSCs from any posttransplantation immune or inflammatory reactions (MITAL et al., 2010). The second point is the pharmacological character of busulfan. Busulfan is a chemotherapeutic agent that is mostly used in low doses and for a long time in the treatment of chronic myeloid leukemia (SUTTORP and MILLOT, 2010), and before any allogeneic transplantation of hematopoietic cells, it is administered as a myeloablastive agent (BARTELINK et al., 2014). The last point is related to the BM-MSCs character, which is shown to be not only hypo-immunogenic but also to have immune-surveillance or immunosuppressive properties upon transplantation, and to be a good candidate for allogeneic transplantation (AI et al., 2012). Interestingly, intravenous transfusion of BM-MSCs was demonstrated to have immunomodulatory effects for the production of antisperm antibodies in allogeneic transplantations in mice after testicular ruptures (AGHAMIR et al., 2014). Therefore, allotransplantation of MSCs may be considered as the method of choice for azoospermia cell therapy.

The histomorphometric indices of the treated seminiferous tubules in the guinea pigs interestingly showed that cellular diameter and area, as well as total diameter and cross-sectional area were greater after cell therapy than in the control negative group. This phenomenon of an increase in the volume of seminiferous tubules may be caused 
by the increase in the area of the seminiferous tubules before and after transplantation. Before transplantation, as observed in the increase in the luminal area in the azoospermic group, the decrease in cellular layers may cause a reduction in the resistance of the tubal structure and the collapse of some tubules under the intratubular hydrostatic pressure in the seminiferous tubules. Therefore, the increase in the spaces in the testis may result in an increase in the diameter of the other tubes. Simultaneously, the increase in the diameter of the non-collapsed tube after azoospermia induction and also the increase in the total area of the tubes during this period before treatment may reduce the ability to contract of the contractile myofibroblast cells in the peritubular layer, so altogether these disorders could decrease intratubular hydrostatic pressure. It is necessary to state that although the role of this pressure in the mechanism of spermatogenesis in guinea pig has not yet been clarified, pressure reduction may be one reason for the increase in the diameter of the cellular layer in the AT-MSCs treated tubes. The increase in the cellular area of the seminiferous tubules in the cell therapy group might also be caused by the greater space for Sertoli cells non-affected with busulfan in the germinal layer, which caused the cells to cover a more two-dimensional area than the normal group. On the other hand, the method of cell therapy in the guinea pig model, performed by direct injection of cells into the seminiferous tubules, in comparison with other species, including rats and hamsters which were injected via the ductus efferent (MEHRABANI et al., 2015b; TAMADON et al., 2015; RAHMANIFAR et al., 2016), may also be another reason for the increase in the diameter of the tubes after cell therapy. The loosened structure of busulfan treated tubules might not be able to resist the pressure of direct injection of cell suspension, and so they dilated. However, the findings of spermatogenesis indices in the cell therapy group showed that the number of cells did not differ between the normal intact tubules and the treated groups, which shows an increase in volume of the cellular layer, although the diameter of cellular layer had increased. However cell therapy could not reverse all the side effects of busulfan treatment and the enlarged inter-Sertoli cell spaces appeared to be filled with a lower number of germinal epithelial cells than expected.

In conclusion, our morphometric findings noted a new feature of cell therapy for azoospermia in a guinea pig azoospermia model that could facilitate the fast repair of pathological changes in testicular seminiferous tubules. BM-MSCs were effective in treatment of azoospermia in the guinea pig model, and restored the fertility of busulfan induced azoospermic animals after transplantation of BM-MSCs. These results could open a window in the future to the possibility of BM-MSCs transplantation in the treatment of azoospermia in humans, but more studies should be undertaken to verify this issue. 
M. Hajihoseini et al.: Azoospermia stem cell therapy

\begin{abstract}
Acknowledgements
We thank Dr. Mehdi Dianatpour and Dr. Zahra Khodabandeh for their valuable advice and Dr. Farhad Rahmanifar, Dr. Iman Razeghian Jahromi and Mr. Shahrokh Zare for technical support to this study. The authors wish to thank the technical and equipment support of the Stem Cell and Transgenic Technology Research Center, Shiraz University of Medical Sciences, and the official and funding support of Shiraz Branch, Islamic Azad University, and Fars Science and Research Branch, Islamic Azad University, Fars, Shiraz, Iran. This study was funded by Islamic Azad University, Shiraz Branch, Shiraz, Iran (grant no. 91.15007; date 19/1/2013). This study is a part of a PhD thesis undertaken in Stem Cell and Transgenic Technology Research Center, Shiraz University of Medical Sciences, Shiraz, Iran.
\end{abstract}

\title{
References
}

AGHAMIR, S. M. K., A. SALAVATI, R. YOUSEFIE, Z. TOOTIAN, N. GHAZALEH, M. JAMALI, P. AZIMI (2014): Does bone marrow-derived mesenchymal stem cell transfusion prevent antisperm antibody production after traumatic testis rupture? Urology 84, 82-86.

AI, J., S. EBRAHIMI, A. KHOSHZABAN, T. S. JAFARZADEH KASHI, D. MEHRABANI (2012): Tissue engineering using human mineralized bone xenograft and bone marrow mesenchymal stem cells allograft in healing of tibial fracture of experimental rabbit model. Iran. Red Crescent Med. J. 14, 96-103.

ALIBORZI, G., A. VAHDATI, D. MEHRABANI, S. EBRAHIM HOSSEINI, A. TAMADON (2016): Isolation, characterization and growth kinetic comparison of bone marrow and adipose tissue mesenchymal stem cells of guinea pig. Int. J. Stem Cells 9, 115-123.

ASADI-YOUSEFABAD, S.-L., A. KHODAKARAM-TAFTI, M. DIANATPOUR, D. MEHRABANI, S. ZARE, A. TAMADON, S. NIKEGHBALIAN, A. RAAYAT-JAHROMI, S. AHMADLOU (2015): Genetic evaluation of bone marrow-derived mesenchymal stem cells by a modified karyotyping method. Comp. Clin. Pathol. 24, 1361-1366.

BARTELINK, I., E. VAN REIJ, C. GERHARDT, E. VAN MAARSEVEEN, A. DE WILDT, B. VERSLUYS, C. LINDEMANS, M. BIERINGS, J. J. BOELENS (2014): Fludarabine and exposure-targeted busulfan compares favorably with busulfan/cyclophosphamide-based regimens in pediatric hematopoietic cell transplantation: maintaining efficacy with less toxicity. Biol. Blood Marrow Transplant. 20, 345-353.

BEROOKHIM, B. M., P. N. SCHLEGEL (2014): Azoospermia due to spermatogenic failure. Urol. Clin. North Am. 41, 97-113.

BUCAY, N., M. YEBRA, V. CIRULLI, I. AFRIKANOVA, T. KAIDO, A. HAYEK, A. M. MONTGOMERY (2009): A novel approach for the derivation of putative primordial germ cells and sertoli cells from human embryonic stem cells. Stem Cells 27, 68-77.

CAKICI, C., B. BUYRUKCU, G. DURUKSU, A. H. HALILOGLU, A. AKSOY, A. ISIK, O. ULUDAG, H. USTUN, C. SUBASI, E. KARAOZ (2013): Recovery of fertility in azoospermia rats after injection of adipose-tissue-derived mesenchymal stem cells: the sperm generation. BioMed Res. Int. 2013, 529589. 
CHEN, H., Q. L. TANG, X. Y. WU, L. C. XIE, L. M. LIN, G. Y. HO, L. MA (2015): Differentiation of human umbilical cord mesenchymal stem cells into germ-like cells in mouse seminiferous tubules. Mol. Med. Rep. 12, 819-828.

DE ROOIJ, D. G., R. VERGOUWEN (1990): The estimation of damage to testicular cell lineages. Prog. Clin. Biol. Res. 372, 467-480.

DRUSENHEIMER, N., G. WULF, J. NOLTE, J. H. LEE, A. DEV, R. DRESSEL, J. GROMOLL, J. SCHMIDTKE, W. ENGEL, K. NAYERNIA (2007): Putative human male germ cells from bone marrow stem cells. Soc. Reprod. Fertil. Suppl. 63, 69-76.

EHNINGER, A., A. TRUMPP (2011): The bone marrow stem cell niche grows up: mesenchymal stem cells and macrophages move in. J. Exp. Med. 208, 421-428.

GNECCHI, M., L. G. MELO (2009): Bone marrow-derived mesenchymal stem cells: isolation, expansion, characterization, viral transduction, and production of conditioned medium. Methods Mol. Biol. 482, 281-294.

GOOSSENS, E., D. VAN SAEN, H. TOURNAYE (2013): Spermatogonial stem cell preservation and transplantation: from research to clinic. Hum. Reprod. 28, 897-907.

GUDELOGLU, A., S. J. PAREKATTIL (2013): Update in the evaluation of the azoospermic male. Clinics 68, 27-34.

JIANG, Y., B. N. JAHAGIRDAR, R. L. REINHARDT, R. E. SCHWARTZ, C. D. KEENE, X. R. ORTIZ-GONZALEZ, M. REYES, T. LENVIK, T. LUND, M. BLACKSTAD (2002): Pluripotency of mesenchymal stem cells derived from adult marrow. Nature 418, 41-49.

LASSALLE, B., M. A. MOUTHON, L. RIOU, V. BARROCA, M. COUREUIL, F. BOUSSIN, J. TESTART, I. ALLEMAND, P. FOUCHET (2008): Bone marrow-derived stem cells do not reconstitute spermatogenesis in vivo. Stem Cells 26, 1385-1386.

LEATHERMAN, J. (2013): Stem cells supporting other stem cells. Front. Genet. 4, 257.

LUE, Y., K. ERKKILA, P. Y. LIU, K. MA, C. WANG, A. S. HIKIM, R. S. SWERDLOFF (2007): Fate of bone marrow stem cells transplanted into the testis: potential implication for men with testicular failure. Am. J. Pathol. 170, 899-908.

MAHDIYAR, P., S. ZARE, R. ROBATI, M. DIANATPOUR, K. TORABI, A. TAMADON, I. RAZEGHIAN JAHROMI, A. TAMADON, D. MEHRABANI (2014): Isolation, culture, and characterization of human dental pulp mesenchymal stem cells. Int. J. Pediatr. 2, 44.

MANSOUR, A., G. ABOU-EZZI, E. SITNICKA, S. E. W. JACOBSEN, A. WAKKACH, C. BLINWAKKACH (2012): Osteoclasts promote the formation of hematopoietic stem cell niches in the bone marrow. J. Exp. Med. 209, 537-549.

MEHRABANI, D., R. BAHRAMI NAZARABADI, M. DIANATPOUR, A. VAHDATI, A. TAMADON, M. KASRAEIAN, S. ZARE, F. GHOBADI (2015a): Growth kinetics, characterization and plasticity of human menstrual blood stem cells. Iran. J. Med. Sci. 41, 132-139.

MEHRABANI, D., M. A. HASSANSHAHI, A. TAMADON, S. ZARE, S. KESHAVARZ, F. RAHMANIFAR, M. DIANATPOUR, Z. KHODABANDEH, I. JAHROMI, N. TANIDEH, M. RAMZI, H. AQABABA, O. KUHI-HOSEINABADI (2015b): Adipose tissue-derived 
mesenchymal stem cells repair germinal cells of seminiferous tubules of busulfan-induced azoospermic rats. J. Hum. Reprod. Sci. 8, 103-110.

MEHRABANI, D., F. RAHMANIFAR, M. MELLINEJAD, A. TAMADON, M. DIANATPOUR, S. ZARE, I. R. JAHROMI, F. GHOBADI (2014): Isolation, culture, characterization, and adipogenic differentiation of heifer endometrial mesenchymal stem cells. Comp. Clin. Pathol. 24, 1159-1164.

MEINHARDT, A., M. P. HEDGER (2011): Immunological, paracrine and endocrine aspects of testicular immune privilege. Mol. Cell Endocrinol. 335, 60-68.

MITAL, P., G. KAUR, J. M. DUFOUR (2010): Immunoprotective sertoli cells: making allogeneic and xenogeneic transplantation feasible. Reproduction 139, 495-504.

MONSEFI, M., B. FEREYDOUNI, L. ROHANI, T. TALAEI (2013): Mesenchymal stem cells repair germinal cells of seminiferous tubules of sterile rats. Iran. J. Reprod. Med. 11, 537-544.

MORRISON, S. J., D. T. SCADDEN (2014): The bone marrow niche for haematopoietic stem cells. Nature 505, 327-334.

NAYERNIA, K., J. H. LEE, N. DRUSENHEIMER, J. NOLTE, G. WULF, R. DRESSEL, J. GROMOLL, W. ENGEL (2006): Derivation of male germ cells from bone marrow stem cells. Lab. Invest. 86, 654-663.

NIEDERKORN, J. Y. (2006): See no evil, hear no evil, do no evil: the lessons of immune privilege. Nat. Immunol. 7, 354-359.

NOLLER, D. W., C. J. FLICKINGER, S. S. HOWARDS (1977): Duration of the cycle of the seminiferous epithelium in the guinea pig determined by tritiated thymidine autoradiography. Biol. Reprod. 17, 532-534.

O'BRIEN, K. L. F., A. C. VARGHESE, A. AGARWAL (2010): The genetic causes of male factor infertility: a review. Fertil. Steril. 93, 1-12.

PANAHI, M., N. KARIMAGHAI, F. RAHMANIFAR, A. TAMADON, A. VAHDATI, D. MEHRABANI, O. KOOHI-HOSSEINABADI, M. SEPEHRIMANESH (2014): Stereological evaluation of testes in busulfan-induced infertility of hamster. Comp. Clin. Pathol. 24, 10511056.

RAHMANIFAR, F., A. TAMADON, D. MEHRABANI, S. H. ZARE, S. ABASI, S. KESHAVARZ, M. DIANATPOUR, Z. KHODABANDEH, I. RAZEGHIAN JAHROMI, O. KOOHIHOSEINABADI (2016): Histomorphometric evaluation of treatment of rat azoospermic seminiferous tubules by allotransplantation of bone marrow-derived mesenchymal stem cells. Iran. J. Basic Med. Sci. 19, 653-661.

RODRÍGUEZ-CASURIAGA, R., A. GEISINGER, F. F. SANTIÑAQUE, B. LÓPEZ-CARRO, G. A. FOLLE (2011): High-purity flow sorting of early meiocytes based on DNA analysis of guinea pig spermatogenic cells. Cytometry A 79A, 625-634.

SABBAGHI, M. A., A. R. BAHRAMI, B. FEIZZADE, S. M. KALANTAR, M. M. MATIN, M. KALANTARI, A. AFLATOONIAN, M. SAEINASAB (2012): Trial evaluation of bone marrow derived mesenchymal stem cells (MSCs) transplantation in revival of spermatogenesis in testicular torsion. Middle East Fertil. Soc. J. 17, 243-249. 
SHATERZADEH-YAZDI, H., D. MEHRABANI,A. KHODAKARAM-TAFTI, M. DIANATPOUR, S. H. ZARE, A. TAMADON, I. RAZEGHIAN-JAHROMI (2015): Osteogenic potential of subcutaneous adipose-derived stem cells in a rabbit model. Online J. Vet. Res. 19, 436-445.

SUTTORP, M., F. MILLOT (2010): Treatment of pediatric chronic myeloid leukemia in the year 2010: use of tyrosine kinase inhibitors and stem-cell transplantation. Hematology Am. Soc. Hematol. Educ. Program 2010, 368-376.

TAMADON, A., D. MEHRABANI, F. RAHMANIFAR, A. RAAYAT JAHROMI, M. PANAHI, S. ZARE, Z. KHODABANDEH, I. RAZEGHIAN JAHROMI, N. TANIDEH, M. DIANATPOUR, M. RAMZI, O. KOOHI-HOSEINABADI (2015): Induction of spermatogenesis by bone marrow-derived mesenchymal stem cells in busulfan-induced azoospermia in hamster. Int. J. Stem Cells 8, 134-145.

YANG, S., J. BO, H. HU, X. GUO, R. TIAN, C. SUN, Y. ZHU, P. LI, P. LIU, S. ZOU (2012): Derivation of male germ cells from induced pluripotent stem cells in vitro and in reconstituted seminiferous tubules. Cell Prolif. 45, 91-100.

ZAHKOOK, S. A., A. ATWA, M. SHAHAT, A. M. MANSOUR, S. BAKRY (2014): Mesenchymal stem cells restore fertility in induced azoospermic rats following chemotherapy administration. J. Reprod. Infertil. 5, 50-57.

ZHANG, D., X. LIU, J. PENG, D. HE, T. LIN, J. ZHU, X. LI, Y. ZHANG, G. WEI (2014): Potential spermatogenesis recovery with bone marrow mesenchymal stem cells in an azoospermic rat model. Int. J. Mol. Sci. 15, 13151-13165.

Received: 9 December 2015

Accepted: 26 February 2016

HAJIHOSEINI, M., A. VAHDATI, S. E. HOSSEINI, D. MEHRABANI, A. TAMADON: Indukcija spermatogeneze nakon terapije azoospermične zamorčadi matičnim stanicama. Vet. arhiv 87, 333-350, 2017.

SAŽETAK

Mezenhimne matične stanice podrijetlom iz koštane srži (MMSKS) pružaju velike mogućnosti alternativnog izvora u regenerativnoj medicini. Ovo je istraživanje provedeno radi određivanja učinka MMSKS u svrhu liječenja azoospermije u zamorčadi izazvane busulfanom. MMSKS su bile izdvojene iz srži bedrene kosti od šestero odraslih zamorčića kao donorske skupine te im je određena morfologija, markeri te osteogenična i adipogenična diferencijacija. Doza od $40 \mathrm{mg} / \mathrm{kg}$ busulfana bila je zamorčićima primijenjena u razmaku od 21 dana. Tridesetipet dana nakon posljednje primjene busulfana provedena je transplantacija $1 \times 10^{6}$ MMSKS u sjemenonosne tubule lijevih sjemenika. Desni sjemenik uzet je kao pozitivna busulfan kontrola. Sjemenici donorske skupine uzeti su kao netaknuta normalna skupina. Nakon stanične terapije u trajanju od 60 dana provedena je histopatološka i histomorfometrijska prosudba sjemenika. Sjemenonosni tubuli obrađeni MMSKS, slično kao i neobrađena kontrolna skupina, pokazivali su normalnu spermatogenezu u usporedbi s busulfanom induciranim azoospermičnim sjemenicima. Zaključno se može reći da su MMSKS bile učinkovite u liječenju azoospermije na modelu zamorčadi te da se plodnost u azoospermičnih zamorčića vratila nakon transplantacije MMSKS. Stoga ovo istraživanje može ubuduće otvoriti prozor za mogućnost transplantacije MMSKS u svrhu liječenja azoospermije u čovjeka, premda su za potvrdu toga potrebna daljnja istraživanja.

Ključne riječi: koštana srž, mezenhimne matične stanice, busulfan, azoospermija, zamorče 